\title{
Circulating thyroid hormone levels in children
}

\author{
J. M. CORCORAN, C. J. EASTMAN, J. N. CARTER, AND L. LAZARUS \\ From the Garvan Institute of Medical Research, St. Vincent's Hospital, Sydney, NSW, Australia
}

SUMMARY Extensive use of radioimmunoassay for routine measurement of serum thyroid hormones in paediatric thyroid disorders showed inconsistencies between laboratory results based upon adult criteria and clinical observation. To resolve this disparity, serum triiodothyronine (T3) and thyroxine (T4) levels were measured by radioimmunoassay in 354 healthy children aged between 3 weeks and 17 years.

The mean serum T3 concentration in children up to 10 years of age was $1.94 \pm 0.35 \mathrm{ng} / \mathrm{ml}$ (SD) which was higher than the mean serum T3 of $1.37 \pm 0.25 \mathrm{ng} / \mathrm{ml}$ in healthy adults. Similarly, the mean serum T4 of $10 \pm 2 \cdot 5 \mu \mathrm{g} / 100 \mathrm{ml}$ was higher than the adult mean serum T4 of $8 \cdot 5 \pm 1 \cdot 5 \mu \mathrm{g} / 100 \mathrm{ml}$. Neither concentration changed significantly from 3 weeks to 10 years of age, nor was there any sex difference. In girls serum T3 and T4 concentrations declined gradually from age 10 to maturity. A perimenarcheal nadir observed in the T4 data was thought to reflect the joint effects of the age-dependent fall in circulating T4 and the concomitant oestrogendependent rise in thyroxine-binding globulin. In boys the decline in serum T3 occurred approximately 2 years later than in the girls. These observations show that the normal ranges for serum T3 and T4 in children are higher than those in adults and that reference to normal adult ranges may lead to misclassification in diagnosis and monitoring of paediatric thyroid disorders.

Simple and rapid radioimmunoassays for measurement of serum thyroxine (T4) and triiodothyronine (T3) are now readily available for assessment of thyroid function in children, yet the criteria for normal thyroid function are mostly derived from adult data (Fisher, 1973). Using a competitive protein binding assay, O'Halloran and Webster (1972) reported that after the neonatal surge in thyroid hormone concentration, serum T4 declined till the age of one year to stabilize at a mean level of $9 \cdot 2 \mu \mathrm{g} / 100 \mathrm{ml}$. Murray et al. (1971) showed higher serum T4 and T3 resin uptake levels in childhood which declined slowly with age until late adolescence. Published information on circulating T3 levels is, however, sparse and conflicting. AvRuskin et al. (1973) found no significant change in six groups of children aged between 1 and 18 years, the mean serum $\mathrm{T} 3$ levels being within the normal adult range. By contrast, Rubenstein et al. (1973) reported higher serum T3 levels in young children with a fall of approximately $0.05 \mathrm{ng} / \mathrm{ml}$ per decade.

After extensive routine use of serum T3 estimations, it has become apparent that circulating T3 levels in children are higher than in adults, and that many clinically hypothyroid children with raised serum thyroid-stimulating hormone (TSH) levels

Received 18 February 1977 have T3 levels within the normal adult range. This study was undertaken to determine serum T3 and T4 levels in normal children from 3 weeks to 17 years of age.

\section{Subjects and methods}

Sera were obtained for estimation of T3, T4, and TSH concentrations in the following groups of children.

(1) 112 children between the ages of 3 weeks and 9 years who were in hospital for elective surgery or minor nonendocrine illnesses. Blood samples were obtained for routine investigations and subsequently donated for this study.

(2) 196 normal schoolgirls aged 9 to 17 years who were participating in a study of endocrine and pubertal relationships conducted by the Garvan Institute of Medical Research in collaboration with the Sydney Human Performance Laboratory. All sera from this group were randomly assayed in two batches at the same time, using the same reagents.

(3) 46 normal schoolboys of three ages, 10, 14, and 16 years, also participating in the above study on whose sera $\mathrm{T} 3$ estimations were 
Table 1 Mean serum triiodothyronine (T3) and thyroxine (T4) levels in group 1, children aged 3 weeks to 9 years

\begin{tabular}{|c|c|c|c|c|c|c|c|c|c|c|}
\hline & \multicolumn{10}{|l|}{ Age (years) } \\
\hline & $<I$ & $I$ & 2 & 3 & 4 & 5 & 6 & 7 & 8 & 9 \\
\hline$\underset{n}{\mathrm{~T} 3 \mathrm{ng} / \mathrm{ml} \pm \mathrm{SD}}$ & $\begin{array}{l}1 \cdot 99 \pm 0 \cdot 32 \\
22\end{array}$ & $\begin{array}{l}2 \cdot 00 \pm 0 \cdot 36 \\
18\end{array}$ & $\begin{array}{l}1 \cdot 82 \pm 0 \cdot 28 \\
9\end{array}$ & $\begin{array}{l}2 \cdot 05 \pm 0 \cdot 30 \\
9\end{array}$ & $\begin{array}{l}1 \cdot 86 \pm 0 \cdot 25 \\
10\end{array}$ & $\begin{array}{l}2 \cdot 06 \pm 0 \cdot 38 \\
10\end{array}$ & $\begin{array}{l}1.97 \pm 0 \cdot 38 \\
11\end{array}$ & $\begin{array}{l}1 \cdot 87 \pm 0 \cdot 33 \\
15\end{array}$ & $\begin{array}{l}1 \cdot 96 \pm 0 \cdot 36 \\
16\end{array}$ & $\begin{array}{l}1 \cdot 92 \pm 0 \cdot 31 \\
11\end{array}$ \\
\hline $\begin{array}{c}\mathrm{T} 4 \mu \mathrm{g} / 100 \mathrm{ml} \\
\underset{\mathrm{n}}{ \pm \mathrm{SD}}\end{array}$ & $\begin{array}{l}10 \cdot 5 \pm 2 \cdot 2 \\
20\end{array}$ & $\begin{array}{l}10 \cdot 2 \pm 1 \cdot 8 \\
17\end{array}$ & $\begin{array}{l}10 \cdot 3 \pm 1 \cdot 8 \\
8\end{array}$ & $\begin{array}{l}10 \cdot 6 \pm 3 \cdot 3 \\
6\end{array}$ & $\begin{array}{l}9 \cdot 3 \pm 1 \cdot 8 \\
8\end{array}$ & $\begin{array}{l}9 \cdot 0 \pm 2 \cdot 1 \\
5\end{array}$ & $\begin{array}{l}10 \cdot 7 \pm 3 \cdot 0 \\
10\end{array}$ & $\begin{array}{l}9 \cdot 6 \pm 1 \cdot 4 \\
13\end{array}$ & $\begin{array}{l}9 \cdot 1 \pm 1 \cdot 7 \\
10\end{array}$ & $\begin{array}{l}9 \cdot 4 \pm 0.3 \\
6\end{array}$ \\
\hline
\end{tabular}

Conversion: Traditional units to $S I-\mathrm{T} 3: 1 \mathrm{ng} / \mathrm{ml} \approx 1.536 \mathrm{nmol} / 1 . \mathrm{T} 4: 1 \mu \mathrm{g} / 100 \mathrm{ml} \approx 12.87 \mathrm{nmol} / \mathrm{l}$.

performed in the same assay as a pair-matched subgroup from group 2.

Serum T4 and T3 were measured by specific radioimmunoassays (Corcoran et al., 1973; Eastman et al., 1975). Serum TSH was measured by radioimmunoassay using reagents kindly supplied by the NIAMDD with MRC human TSH 68/38 as standard. Sensitivities of the assays were $0 \cdot 3-1 \cdot 0 \mu \mathrm{U} / \mathrm{ml}$ serum TSH, $0.08 \mathrm{ng} / \mathrm{ml}$ serum $\mathrm{T} 3$, and $0.25 \mu \mathrm{g} /$ $100 \mathrm{ml}$ serum T4. Intra-assay variation for T3 and T4 was $3 \%$, and for TSH $6 \%$. Inter-assay variation was between $11 \%$ and $13 \%$ for all three systems.

\section{Results}

Results are reported as mean \pm 1 SD unless otherwise stated. Statistical analyses were performed using Student's $t$ test. Serum TSH measurements were performed to exclude possible undetected primary hypothyroidism. Values ranged from below assay sensitivity to $7 \mu \mathrm{U} / \mathrm{ml}$ and are not reported in detail.

Group 1: children up to 9 years of age. Results are shown in Table 1, where the mean serum T3 and T4 levels are arranged in single-year sets. There was no significant difference in either mean T3 or T4 levels between any age group, nor was there any sex difference. The mean T3 over the whole group, however, was $1.94 \pm 0.35 \mathrm{ng} / \mathrm{ml}$, range $1 \cdot 2-3.54 \mathrm{ng} /$ $\mathrm{ml}$. This is significantly higher $(P<0.001)$ than the adult mean of $1.37 \pm 0.25 \mathrm{ng} / \mathrm{ml}$ previously reported by this laboratory (Carter et al., 1974). Serum T4 levels ranged from $5 \cdot 5$ to $16 \mu \mathrm{g} / 100 \mathrm{ml}$ with a mean of $10 \pm 2 \cdot 5 \mu \mathrm{g} / 100 \mathrm{ml}$. Compared with the normal adult mean serum T4 of $8 \cdot 5 \pm 1 \cdot 5 \mu \mathrm{g} / 100 \mathrm{ml}$, the difference was highly significant $(P<0 \cdot 001)$. Individual serum T3 and T4 determinations are shown in Figs. 1 and 2 with reference to the normal adult range. Whereas the majority of $\mathrm{T} 4$ determinations fall within the normal adult range, the majority of T3 determinations are above the normal adult range.

Group 2: girls aged 9 to 17 years. Since there were only 2 girls in the 9-year age group, the data have been supplemented by inclusion of results of girls of the same age in group 1, and thus are subject to inter-assay variation. The decline in mean serum $\mathrm{T3}$

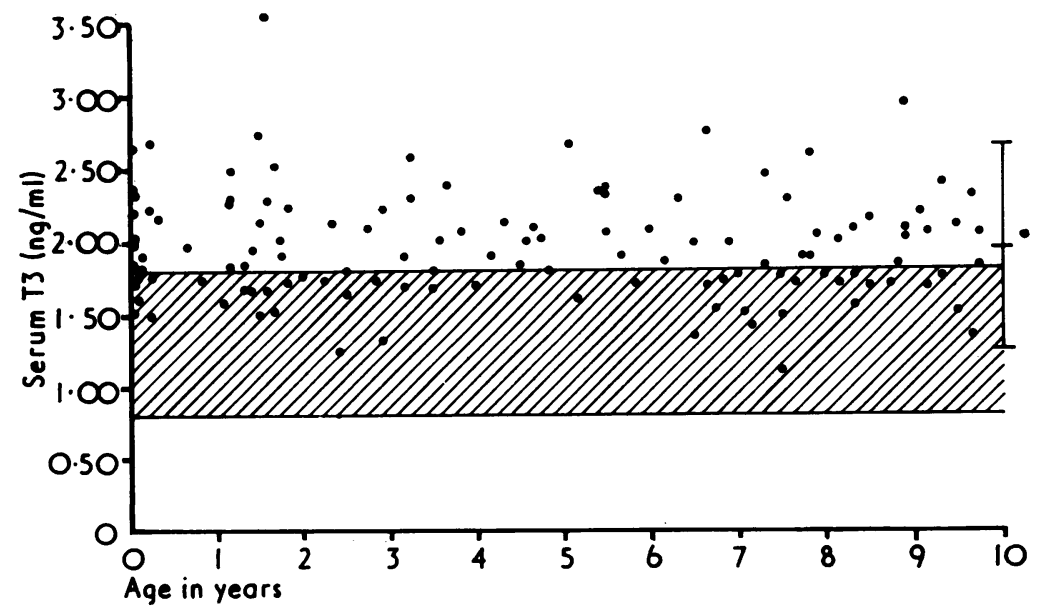

Fig. 1 Individual serum T3 levels in children aged between 3 weeks and 10 years (mean $\pm 2 S D$ is shown on the right). Normal adult range is hatched area. See Table 1 for conversion from traditional units to SI. 


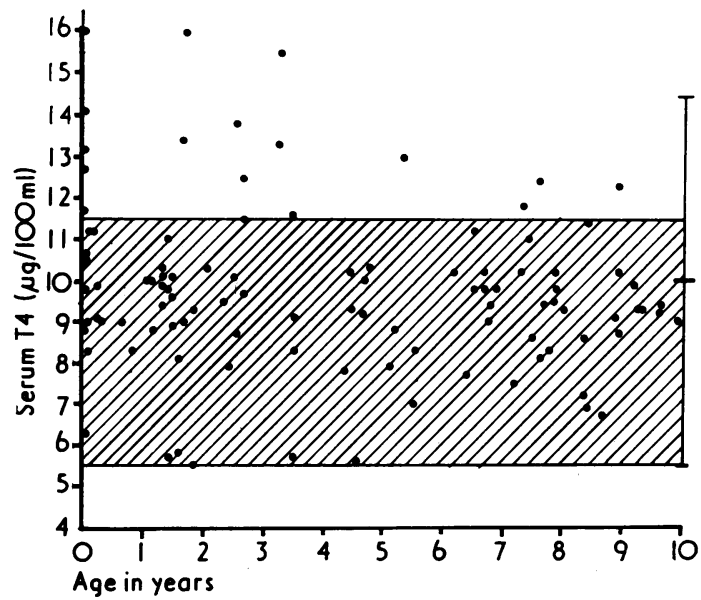

Fig. 2 Individual serum T4 levels in children aged between 3 weeks and 10 years (mean $\pm 2 S D$ is shown on the right). Normal adult range is hatched area.

from $1.92 \mathrm{ng} / \mathrm{ml}$ at age 9 to $1.61 \mathrm{ng} / \mathrm{ml}$ at age 17 is shown in Fig. 3. The fall in serum T3 is significant $(P<0.05)$ by age 14 when compared with the mean T3 levels at age 10. When the data were assessed according to pubertal development there was a highly significant $(\mathrm{P}<0.0001)$ difference between the mean premenarcheal T3 levels of $1.91 \pm 0.26 \mathrm{ng} / \mathrm{ml}$

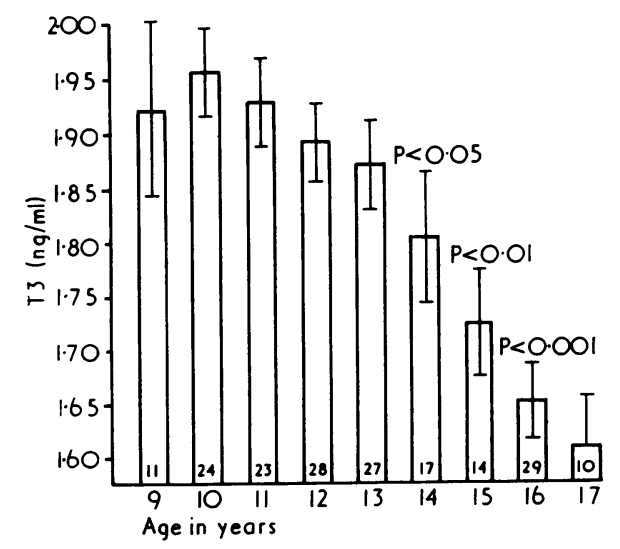

Fig. 3 Mean serum T3 levels showing the decline in values from the age of 9 to 17 years. Bars are 1 SEM. and the mean postmenarchael T3 level of $1.73 \pm$ $0 \cdot 21 \mathrm{ng} / \mathrm{ml}$.

The mean serum T4 levels are shown in Fig. 4. The nadir in serum T4 of $7 \cdot 3 \mu \mathrm{g} / 100 \mathrm{ml}$ corresponds with the average age of menarche (13.1 years) in the girls examined. The decline in serum $\mathrm{T} 4$ at age 13 is significant $(P<0.0001)$ when compared with the 10-year age group. By the age of 17 years the mean T4 level had risen to the normal adult level of $8 \cdot 5 \mu \mathrm{g} / 100 \mathrm{ml}$.

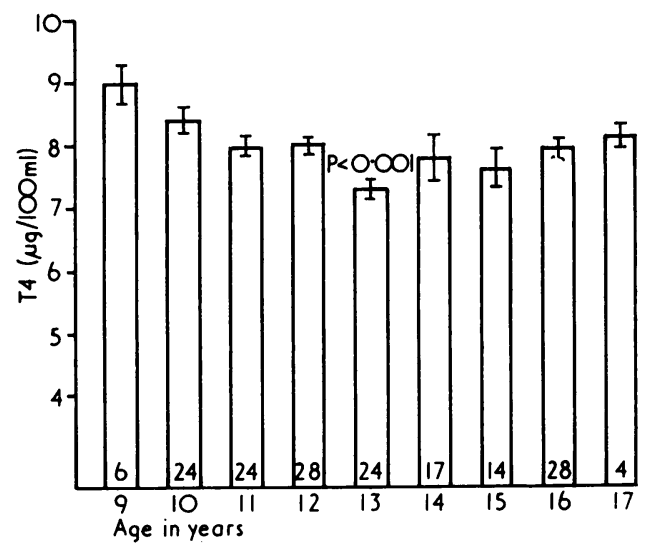

Fig. 4 Mean serum T4 levels in girls aged between 9 and 17 years, showing the premenarcheal nadir. Bars are 1 SEM.

The $T 4 / T 3$ ratios were calculated individually and the mean values for each age group are shown in Table 2. The normal Australian adult ratio in this laboratory is $67 \pm 10$.

Group 3: schoolboys and pair-matched girls. Since male and female levels of T3 are the same both in early childhood and adulthood, a smaller study was carried out to check that the fall in serum T3 in boys followed the same trend to adult values as in pairmatched girls. The results are shown in Table 3 .

Table 3 Comparison of circulating T3 levels $(\mathrm{ng} / \mathrm{ml} \pm$ $S D)$ in pair-matched girls and boys in group 3

\begin{tabular}{llll}
\hline & 10 years & 14 years & 16 years \\
\hline Girls & $1 \cdot 95 \pm 0 \cdot 19$ & $1 \cdot 81 \pm 0 \cdot 15$ & $1 \cdot 56 \pm 0 \cdot 22$ \\
Boys & $1 \cdot 94 \pm 0 \cdot 28$ & $2 \cdot 00 \pm 0 \cdot 18$ & $1 \cdot 85 \pm 0 \cdot 27$ \\
\hline
\end{tabular}

Table 2 Mean circulating T4:T3 ratios in girls in group 2

\begin{tabular}{llllllllll}
\hline & Age (years) & & & & & & \\
\cline { 2 - 10 } & 9 & 10 & 11 & 12 & 13 & 14 & 15 & 16 & 17 \\
\hline T4:T3 & $46 \cdot 9(50 \cdot 0)$ & $42 \cdot 9$ & $42 \cdot 0$ & $42 \cdot 3$ & $39 \cdot 0$ & $43 \cdot 0$ & $43 \cdot 8$ & $48 \cdot 5$ & $52 \cdot 8$ \\
\hline
\end{tabular}


Early in adolescence mean levels were the same (age $10,1.94 \mathrm{ng} / \mathrm{ml}$ ). At age 16 , however, the mean T3 for boys $(1 \cdot 85 \pm 0.27 \mathrm{ng} / \mathrm{ml})$ was still maintained at the same level as for 14-year-old girls (1.81 \pm $0.15 \mathrm{ng} / \mathrm{ml}$ ), while the mean serum $\mathrm{T} 3$ in the corresponding female age group had fallen to $1 \cdot 56 \pm 0 \cdot 22 \mathrm{ng} / \mathrm{ml}$. The decrease in circulating $\mathrm{T} 3$ to adult levels therefore appeared approximately 2 years later in boys than in girls.

\section{Discussion}

This study clearly shows that serum T3 and T4 levels are significantly higher in prepubertal children when compared with normal adults. Serum T3 levels decline steadily from around the onset of puberty to normal adult levels sometime after the age of 17 years. Serum T4 levels show a similar but less marked decline and reach a nadir in girls at the time of menarche. Although the relative changes in T3 are small, they are statistically significant and unless estimated in the one assay, may pass unnoticed. Thus, a similar decline may exist in the younger age groups as suggested by Rubenstein et al. (1973), but it was not detected in this study. The marked fall in T3 compared with the smaller fall in $\mathrm{T} 4$ is shown by the rise in $\mathrm{T} 4 / \mathrm{T} 3$ ratios with age.

Serum T4 levels were approximately 10 to $15 \%$ higher than those previously reported by other workers and tabulated in the review of Fisher (1973). As the serum T4 concentration estimated by radioimmunoassay is approximately $15 \%$ higher than that obtained by competitive protein binding analysis (Chopra, 1972), these results are consistent with previous reports. Our absolute values for serum T3 in children are higher than those reported by Rubenstein et al. (1973) and AvRuskin et al. (1973), though the mean serum T3 levels in adults obtained by these workers and ourselves are comparable. Apart from the considerable differences in the numbers of children studied, which may have influenced mean serum T3 levels, there is no obvious explanation for this disparity. Thyroid disease, alterations in circulating thyroid hormone binding proteins, iodine intake, nutrition, and associated nonthyroidal illness are potent determinants of circulating T3 levels. As T3 is derived mainly from extrathyroidal monodeiodination of $\mathrm{T} 4$, factors inhibiting conversion of $\mathrm{T} 4$ to $\mathrm{T} 3$, such as nonthyroidal illness (Carter et al., 1974) and decreased caloric intake (Spaulding et al., 1976), result in decreased circulating T3 levels. In our experience, children hospitalized for minor illnesses, and who are not eating normally, may exhibit decreased serum T3 levels characteristic of the sick euthyroid state. Although care was taken to exclude such children from group 1 in this study, some of the children with lower T3 levels may reflect this problem. Whether associated illness and differences in nutrition and iodine intake account for the differences between serum T3 levels reported in this and other studies remains speculative.

Thyroxine degradation rates, when measured per unit body weight, are increased in children compared with adults (Haddad, 1960; Hung et al., 1965). It follows that higher serum T4 levels are consistent with higher production rates, and hence increased thyroidal secretion rates in children. The kinetics of T3 metabolism in children are not known. Assuming the degradation rate for $\mathrm{T} 3$ in children is not less than that in adults, it is probable that thyroidal T3 secretion is also increased. Furthermore, since T3 and $\mathrm{T} 4$ are secreted in the same proportions as they occur in the thyroid gland and as the thyroidal T3:T4 ratios are similar in the fetus and adult (Fisher et al., 1973), increased T4 output should be accompanied by increased T3 secretion. In our study the serum T3 levels were increased to a greater extent than $\mathrm{T} 4$, as evidenced by the $\mathrm{T} 4 / \mathrm{T} 3$ ratios, suggesting a relative increase in $\mathrm{T} 3$ production compared with T4. As T3 is derived mainly from T4 it is highly likely that T4 to T3 conversion is enhanced in the well nourished, healthy child.

The profile of mean T4 levels of perimenarcheal girls as shown in Fig. 4 is difficult to explain. Since oestrogens have a profound effect in raising thyroxine binding globulin and thus circulating T4 levels, it is possible that the profile reported is the outcome of an age-dependent fall in serum T4 and an oestrogendependent rise after menarche.

This study has confirmed our impressions, based upon large numbers of serum thyroid hormone estimations in children, that serum T3 and T4 levels are higher in children compared with adults. These results complement published studies of serum thyroid hormone concentrations in the fetus at term (Lieblich and Utiger 1973; Eastman et al., 1973; Fisher et al., 1973), during early neonatal life and infancy (Montalvo et al., 1973, Erenberg et al., 1974), and provide a basis for definition of normal ranges for thyroid function tests from birth to maturity. This is of great importance in the assessment of thyroid function in children with suspected thyroid disease. Unless laboratories are aware of the higher normal range in children, erroneous diagnoses of hyperthyroidism in clinically suspect but euthyroid children, and of euthyroidism in mildly hypothyroid children, whether treated or untreated, will occur. 
We thank Mss. C. Batley, M. Duckett, and M. Muir for expert help; St. Margaret's Children's Hospital, Darlinghurst, for serum samples from young children; and the Sydney Human Performance Laboratory for permission to use samples obtained from older children. This work was supported by a grant from the National Health and Medical Research Council.

\section{References}

AvRuskin, T. W., Tang, S. C., Shenkman, L., Mitsuma, T., and Hollander, C. S. (1973). Serum triiodothyronine concentrations in infancy, childhood, adolescence and pediatric thyroid disorders. Journal of Clinical Endocrinology and Metabolism, 37, 235-237.

Carter, J. N., Eastman, C. J., Corcoran, J. M., and Lazarus, L. (1974). Effect of severe chronic illness on thyroid function. Lancet, 2, 971-974.

Chopra, I. J. (1972). Radioimmunoassay for measurement of thyroxine in unextracted serum. Journal of Clinical Endocrinology and Metabolism, 34, 938-947.

Corcoran, J. M., Eastman, C. J., Ekins, R. P., and Paul, W. (1973). Production of antisera for radioimmunoassay of thyroxine. Journal of Endocrinology, 58, xxii.

Eastman, C. J., Corcoran, J. M., Jequier, A., Ekins, R. P., and Williams, E. S. (1973). Triiodothyronine concentration in cord and maternal sera at term. Clinical Science and Molecular Medicine, 45, 251-255.

Eastman, C. J., Corcoran, J. M., Ekins, R. P., Williams, E. S., and Nabarro, J. D. N. (1975). The radioimmunoassay of triiodothyronine and its clinical application. Journal of Clinical Pathology, 28, 225-230.

Erenberg, A., Phelps, D. L., Lam, R., and Fisher, D. A. (1974). Total and free thyroid hormone concentrations in the neonatal period. Pediatrics, 53, 211-216.
Fisher, D. A. (1973). Advances in the laboratory diagnosis of thyroid disease. Journal of Pediatrics, 82, 1-9.

Fisher, D. A., Dussault, J. H., Hobel, C. J., and Lam, R. (1973). Serum and thyroid gland triiodothyronine in the human fetus. Journal of Clinical Endocrinology and Metabolism, 36, 397-400.

Haddad, H. M. (1960). Rates of $I^{131}$-labeled thyroxine metabolism in euthyroid children. Journal of Clinical Investigation, 39, 1590-1594.

Hung, W., Gancayco, G. P., and Heald, F. P. (1965). Radiothyroxine metabolism in euthyroid adolescent males in different stages of sexual maturation. Pediatrics, 35, 76-81.

Lieblich, J. M., and Utiger, R. D. (1973). Triiodothyronine in cord serum. Journal of Pediatrics, 82, 290-292.

Montalvo, J. M., Wahner, H. W., Mayberry, W. E., and Lum, R. K. (1973). Serum triiodothyronine, total thyroxine, and thyroxine to triiodothyronine ratios in paired maternalcord sera and at one week and one month of age. Pediatric Research, 7, 706-711.

Murray, I. P. C., Joasoo, A., and Parkin, J. (1971). In vitro thyroid tests in children. Medical Journal of Australia, 1, 77-79.

O'Halloran, M. T., and Webster, H. L. (1972). Thyroid function assays in infants. Journal of Pediatrics, 81, 916919.

Rubenstein, H. A., Butler, V. P., and Werner, S. C. (1973). Progressive decrease in serum triiodothyronine concentrations with human ageing; radioimmunoassay following extraction of serum. Journal of Clinical Endocrinology and Metabolism, 37, 247-253.

Spaulding, S. W., Chopra, I. J., Sherwin, R. S., and Lyall, S. S. (1976). Effect of caloric restriction and dietary composition on serum T3 and reverse T3 in man. Journal of Clinical Endocrinology and Metabolism, 42, 197-200.

Correspondence to Ms. J. M. Corcoran, Endocrine Unit, Woden Valley Hospital, Canberra, ACT 2606, Australia. 